\title{
VALIDASI METODE PENETAPAN KADAR VITAMIN C KULIT JERUK KEPROK (Citrus reticulata) SECARA SPEKTROFOTOMETRI UV-VIS
}

\section{UV-VIS SPECTROPHOTOMETRIC METHOD VALIDATION OF VITAMIN C IN ETHANOL EXTRACT OF TANGERINE (Citrus reticulata Blanco) PEEL}

\author{
Erma Yunita, Emil Nur Arifah, Valentina Febi Tamara \\ Akademi Farmasi Indonesia Yogyakarta, \\ Jl. Veteran, Pandeyan, Umbulharjo, Yogyakarta 55161, Indonesia \\ Email: ermayunita@afi.ac.id (Erma Yunita)
}

\begin{abstract}
ABSTRAK
Banyaknya tanaman yang berkhasiat sebagai obat menjadikan pengobatan tradisional menjadi salah satu pilihan terapi yang banyak digunakan. Salah satunya adalah pemanfaatan kulit jeruk keprok (Citrus reticulata) yang mengandung vitamin C. Adanya peningkatan jumlah penelitian tentang kulit jeruk keprok, utamanya mengenai modifikasi dalam sediaan farmasi, menyebabkan dibutuhkannya validasi metode analisis untuk memastikan jaminan mutu sebuah produk. Tujuan dari penelitian ini adalah melakukan validasi penetapan kadar vitamin $C$ dari ekstrak kulit jeruk keprok secara spektrofotometri UV-Vis. Kulit jeruk keprok dimaserasi menggunakan etanol 70\%. Kadar vitamin C ekstrak kulit jeruk diukur absorbansinya menggunakan spektrofotometri UVVis pada panjang gelombang $274,2 \mathrm{~nm}$. Validasi metode analisis dilakukan dengan menghitung nilai linieritas, presisi, akurasi, batas deteksi, dan batas kuantifikasi. Berdasarkan penelitian dihasilkan persamaan $y=0,069 x-0,01$ dengan nilai $r=0,999$, presisi dengan nilai $\mathrm{RSD}<2 \%$, perolehan kembali pada rentang $97,91-104,16 \%$, batas deteksi 0,239 ppm, dan batas kuantifikasi 0,724 ppm. Kadar vitamin C pada ekstrak kulit jeruk keprok adalah 51,88 mg/g. Hasil penelitian menunjukkan bahwa metode analisis penetapan kadar vitamin C dengan spektrofotometri UV-Vis telah memenuhi parameter validasi analisis.
\end{abstract}

Kata kunci: Citrus reticulate, spektrofotometri UV-Vis, validasi, vitamin C.

\begin{abstract}
Tangerine (Citrus reticulate Blanco) peels contain vitamin $C$ and is potentially used as traditional medicine. The increasing study tangerine peels, especially its modifications in pharmaceutical preparations, leads to the necessity of validation of analytical methods as the part of quality assurance of a given product. The purpose of this study was to validate the determination of vitamin $C$ level in tangerine peels by UV-Vis spectrophotometry. Tangerine peels were macerated using $70 \%$ ethanol. The vitamin $C$ content in tangerine peels extract was determined using UV-Vis spectrophotometry at a
\end{abstract}


wavelength of $274.2 \mathrm{~nm}$. Validation of the analysis method was done by calculating the value of linearity, precision, accuracy, detection limit, and limit of quantification. Based on the research, the equation was $y=0.069 x-0.01$, with $r=0.999$, precision with $R S D$ value of $<2 \%$, recovery in the range of $97.91-104.16 \%$, detection limit of 0.239 , ppm and quantification limit of 0.724 ppm. Vitamin C level in tangerine peels extract was 51.88 $\mathrm{mg} / \mathrm{g}$. The results showed that the analysis method for determination of vitamin $C$ level in tangerine peels with UV-Vis spectrophotometry had met the validation parameters of the analysis.

Key words: Citrus reticulata, UV-Vis spectrophotometry, validation, vitamin C. 


\section{Pendahuluan}

Jeruk memiliki berbagai macam varietas yang ditunjukkan oleh banyaknya kelompok pada marga Citrus (Karsinah et al., 2002). Salah satu jeruk yang terkenal dan sangat mudah dijumpai adalah jeruk keprok (Citrus reticulata) (Zahara, 2002). Jeruk Keprok bermanfaat untuk melindung tubuh terhadap serangan kanker, membantu sistem pertahanan, dan membantu memerangi infeksi virus (Wirakusumah, 2002).

Kulit jeruk merupakan satu di antara sampah-sampah organik yang sering ditemukan khususnya di Indonesia (Zahara, 2002). Di negara berkembang, kulit dari jeruk sudah diolah menjadi parfum karena memiliki bau yang khas (Ball, 1997). Salah satu pemanfaatan lain dari kulit jeruk yaitu untuk kesehatan kulit wajah sehingga hal ini perlu untuk dikembangkan mengingat bagi setiap manusia terlebih di kalangan wanita sangat memperhatikan kulit tubuh khususnya bagi kulit wajah dengan maksud untuk membersihkan, memelihara, ataupun menambah daya tarik (Tranggono dan Latifah, 2007).

Dengan adanya pemanfaatan kulit jeruk, maka dirasa perlu dilakukannya validasi metode analisis untuk memastikan kesesuaian kandungan dengan persyaratan yang ada. Validasi metode analisis merupakan suatu tindakan penilaian terhadap parameter tertentu berdasarkan percobaan laboratorium, untuk membuktikan bahwa parameter tersebut memenuhi persyaratan untuk penggunaannya. Beberapa parameter analisis yang harus dipertimbangkan dalam validasi metode analisis diuraikan dan didefinisikan sebagaimana cara penentuannya. Adapun parameterparameter tersebut antara lain adalah akurasi, presisi, selektifitas, linieritas dan rentang, batas deteksi dan batas kuantitasi, ketangguhan metode, dan kekuatan metode (Harmita, 2004).

Penetapan kadar dapat dilakukan secara analisis menggunakan metode spektrofotometri UV-Vis baik analisis kualitatif maupun kuantitatif. Spektrofotometer UV-Vis mampu memberikan hasil pengukuran kadar vitamin $C$ yang hampir sama dengan nilai nutrisi yang terdapat dalam ekstrak kulit jeruk. Berdasarkan uraian tersebut, maka dilakukan penelitian tentang validasi metode penetapan kadar vitamin C dari ekstrak kulit jeruk keprok secara spektrofotometri UV-Vis. Parameter validasi yang ditetapkan pada 
penelitian ini antara lain linieritas, presisi, akurasi, batas deteksi, dan batas kuantifikasi.

\section{Metode Penelitian}

\section{Alat dan Bahan}

Bahan-bahan yang digunakan pada penelitian ini adalah kulit jeruk keprok yang berasal dari daerah Godean, Yogyakarta. Bahan lain yang digunakan antara lain vitamin C (Extrace $500 \mathrm{mg}$ dari PT. Ethica), etanol 70\% grade A (CV. General Labora), dan akuabides (Ikapharmindo Putra). Intrumen analisis yang digunakan adalah spektrofotometer UV-Vis (Genesys 10S). Jalannya Penelitian

1. Penyiapan ekstrak kulit jeruk keprok

Simplisia kulit jeruk keprok dimaserasi menggunakan etanol $70 \%$ lalu diaduk menggunakan pengaduk elektrik selama 2 jam. Rendaman dibiarkan selama $2 \times 24$ jam terlindung dari cahaya, sambil sesekali diaduk. Hasil maserasi disaring untuk memisahkan ampas dan filtratnya. Maserat dipekatkan dengan alat rotary evaporator dan dikentalkan di atas penangas air hingga terbentuk ekstrak kental.

2. Pembuatan larutan stok Larutan stok standar vitamin C dibuat

dalam konsentrasi 100 ppm dan ekstrak kulit jeruk keprok dibuat pada konsentrasi 10.000 ppm. Larutan stok dibuat dengan menggunakan pelarut akuabides.

3. Penentuan panjang gelombang maksimum vitamin $\mathrm{C}$ Larutan stok konsentrasi 100 ppm sebanyak $\pm 3 \mathrm{ml}$ diukur serapannya dengan spektrofotometer pada panjang gelombang $200-800 \mathrm{~nm}$ dengan menggunakan blanko etanol absolut p.a.

4. Pembuatan kurva baku vitamin C

Kurva baku dibuat dengan cara menghubungkan konsentrasi larutan standar pada seri konsentrasi 4, 6, 8, 10, dan 12 ppm dengan hasil serapannya yang diperoleh dari pengukuran dengan menggunakan spektrofotometri UV pada panjang gelombang maksimum.

5. Validasi metode analisis

Linieritas dilakukan dengan mengukur absorbansi larutan pembanding, kemudian dibuat kurva hubungan antara kadar vs serapan dan ditentukan persamaan regresi linier, koefisien kolerasi $(\mathrm{x})$, dan koefisien kolerasi dari fungsi $\left(\mathrm{V} \mathrm{x}_{0}\right)$. Koefisien fungsi regresi dapat 
dihitung menggunakan rumus pada Persamaan 1-3.

$$
\begin{aligned}
& \mathrm{Sy} / \mathrm{x}=\sqrt{\frac{\sum\left(\mathrm{y}-\mathrm{y}_{1}\right)^{2}}{n-2}} \\
& \mathrm{SXO}=\frac{s y / x}{b} \\
& \mathrm{VXO}=\frac{s y / x}{b} \times 100 \%
\end{aligned}
$$

Koefisien kolerasi dikatakan baik apabila r $\geq 0,998$ (Harmita, 2004).

$$
\text { Presisi dilakukan dengan }
$$
mengukur absorbansi larutan uji, selanjutnya dihitung persentase koefisien kolerasi untuk melihat reprodusibilitas sistem yang digunakan dengan syarat $\mathrm{RSD}<2 \%$ (Harmita, 2004). Pengujian dilakukan sebanyak 7 kali.

Akurasi pada penelitian ini dilakukan dengan metode penambahan baku (standard addition method). Perbandingan antara ekstrak dan baku standar adalah 7:3 dengan rentang 80,100 , dan $120 \%$. Absobansi larutan diukur menggunakan spektrofotometer UV pada panjang gelombang maksimum dan percobaan dilakukan sebanyak 3 kali.

Batas deteksi dan batas
kuantifikasi dapat dihitung secara
statistik melalui garis regresi linier

dari kurva kalibrasi. Nilai pengukuran akan sama dengan nilai $b$ pada persamaan garis linier $y=a+b x$, sedangkan simpangan baku blanko sama dengan simpangan baku residual (sy/x) (Harmita, 2004).

6. Penetapan kadar vitamin C dalam ekstrak kulit jeruk keprok Larutan ekstrak kulit jeruk keprok konsentrasi 100 ppm diukur absorbansinya menggunakan spektrofotometer UV pada panjang gelombang maksimum. Larutan sampel dibuat dalam 3 kali percobaan.

\section{Hasil dan Pembahasan}

Pembuatan Ekstrak Etanol Kulit Jeruk Keprok

Kulit jeruk keprok dimaserasi menggunakan etanol 70\%. Etanol dipilih karena pelarut tersebut merupakan senyawa yang polar sehingga dapat menarik senyawa vitamin $\mathrm{C}$ yang bersifat polar pada kulit jeruk keprok. Rendemen ekstrak yang dihasilkan sebanyak $17,16 \%$.

Penentuan Panjang Gelombang Maksimum Vitamin C

Panjang gelombang maksimum merupakan panjang gelombang dimana terjadi eksitasi elektronik yang memberikan absorbansi maksimum. 
Penentuan panjang gelombang maksimum bertujuan untuk mengukur perubahan absorbansi untuk setiap satuan konsentrasi analisis yang maksimum diperoleh (Gandjar dan Rohman, 2007). Penentuan panjang gelombang maksimum pada ekstrak yang sudah ditentukan akan menghasilkan nilai yang spesifik sehingga memperkecil kemungkinan senyawa lain yang terbaca.

Penentuan panjang gelombang maksimum menggunakan larutan vitamin C 100 ppm yang diukur serapannya pada panjang gelombang 200-800 nm dengan menggunakan blanko akuades. Penelitian yang dilakukan oleh Putri dan Herwidiani (2015) memperoleh panjang gelombang maksimum sebesar $270 \mathrm{~nm}$. Pada penelitian ini didapatkan panjang gelombang maksimum sebesar 274,2 nm. Panjang gelombang tersebut menunjukkan bahwa serapan vitamin $\mathrm{C}$ berada pada daerah UV-Vis karena masuk rentang panjang gelombang 200$800 \mathrm{~nm}$ dengan panjang gelombang UV 200-400 $\mathrm{nm}$ dan visible $400-800 \mathrm{~nm}$. Perbedaan zat dan alat yang digunakan dapat mempengaruhi hasil setiap penelitian.

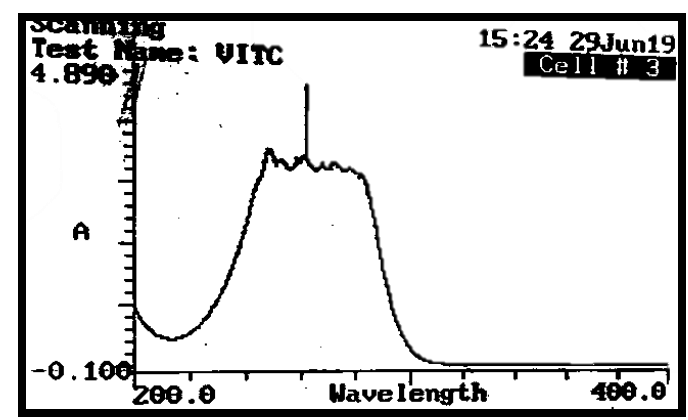

Gambar 1. Panjang gelombang maksimum vitamin C.

Operating Time

Waktu operasional (operating time) merupakan tahap pertama dalam optimasi metode spektrofotometri UVVis. Penentuan operating time dilakukan untuk mengetahui waktu pengukuran yang stabil pada suatu larutan. Adanya serapan yang stabil, memungkinkan tidak terjadinya perubahan struktur kimia pada vitamin C menjadi asam 
Vol.16 No. 01 Juli 2019

dihidroaskorbat karena teroksidasi

Kurva baku merupakan sehingga terjadi penyerapan yang hubungan antara absorbansi dengan sempurna pada panjang gelombang maksimum yang sudah ditentukan. konsentrasi. Pembuatan kurva baku

Pengukuran operating time dilakukan dengan membuat beberapa dilakukan pada konsentrasi 10 ppm dengan panjang gelombang $274,2 \mathrm{~nm}$ selama 30 menit. Pada rentang waktu pengukuran selama 30 menit didapatkan hasil absorbansi yang stabil pada menit pertama hingga menit ke-16 dengan rata-rata nilai absorbansi 0,621.

Pembuatan Kurva Baku Vitamin C konsentrasi larutan mulai dari 4, 6, 8, 10, dan 12 ppm karena pada konsentrasi tersebut didapatkan nilai absorbansi berkisar antara 0,2-0,8. Pada rentang nilai tersebut dihasilkan linieritas yang baik sehingga dengan adanya penambahan kadar maka akan diikuti oleh kenaikan nilai absorbansi yang sebanding.

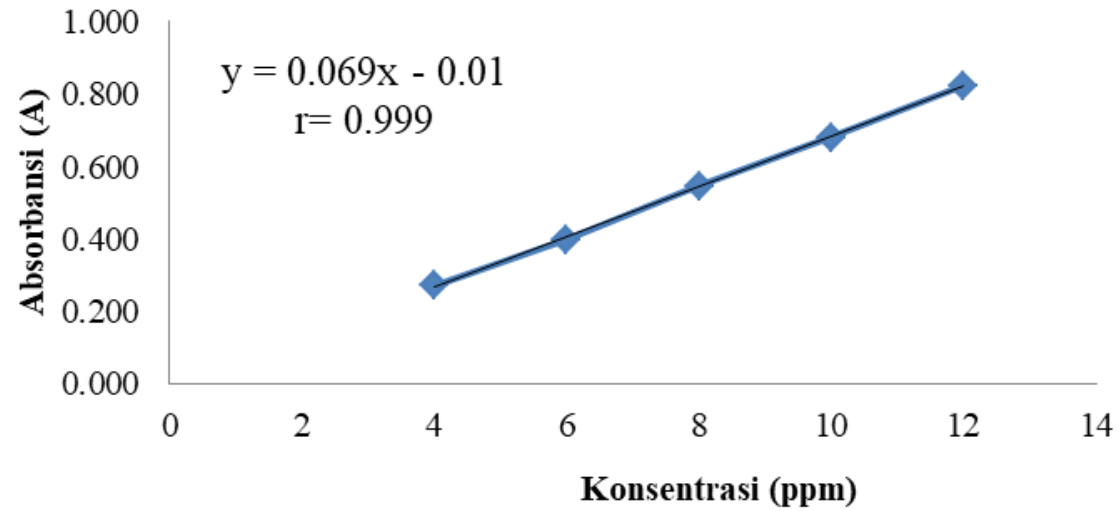

Gambar 2. Kurva baku vitamin C.

Dari seri konsentrasi baku $y=0,069 x-0,01$ dengan koefisien korelasi diperoleh persamaan kurva baku seperti (r) sebesar 0,999. Artinya kurva baku pada Gambar 2 yang dapat digunakan tersebut menggambarkan korelasi positif untuk menghitung kadar vitamin C sempurna dengan semua titik percobaan dalam ekstrak kulit jeruk keprok. Dari terletak pada satu garis lurus dengan hasil perhitungan persamaan regresi kemiringan yang positif.

kurva diperoleh persamaan garis 
Validasi Metode Analisis

Validasi metode analisis perlu dilakukan sebagai elemen penting dari kontrol kualitas. Validasi membantu memberikan jaminan bahwa pengukuran dapat diandalkan (Riyanto, 2014). Validasi metode analisis dilakukan pada penentukan kadar vitamin C secara spektrofotometri UV-Vis. Analisis vitamin C menggunakan spektofotometri dapat dilakukan karena vitamin C merupakan senyawa organik yang memiliki gugus kromofor tak jenuh yang menyebabkan serapan elektronik. Vitamin C juga memiliki auksokrom gugus jenuh yang terikat pada kromofor yang akan mempengaruhi panjang gelombang dan intensitas serapan maksimalnya. Metode kuantitatif untuk pengujian validasi metode ada beberapa parameter yaitu:

\section{Linieritas}

Linieritas adalah kemampuan suatu metode untuk memperoleh hasil-hasil uji yang secara langsung proporsional dengan konsentrasi analit pada kisaran yang diberikan (Gandjar dan Rohman, 2007). Syarat nilai koefesien korelasi ( $r$ ) yang didapat harus memiliki nilai $-1 \leq r \leq 1$, nilai $r=-1$ menggambarkan korelasi negatif sempurna yakni semua titik percobaan terletak pada satu garis lurus yang kemiringannya negatif. Jika $r=+1$ menggambarkan korelasi positif sempurna, yakni semua titik percobaan terletak pada satu garis lurus yang kemiringannya positif. Sedangkan nilai $r=0$ menyatakan tidak ada korelasi sama sekali antara $\mathrm{x}$ dan y (Kealey dan Haines, 2002).

Penentuan kurva baku dilakukan dengan menganalisis serangkaian konsentrasi standar vitamin $\mathrm{C}$ dengan rantang konsentrasi 4-12 ppm. Hasil analisis regresi linier dapat dilihat pada Gambar 2, diperoleh persamaan linier $y=0,069 x-0,01$ dengan koefesien korelasi $(r)=0,999$. Koefisien korelasi memberikan hasil yang linier karena memenuhi kriteria penerimaan. Dengan demikian dapat dikatakan bahwa penetapan kadar vitamin C menggunakan spektrofotometri UVVis memiliki linieritas yang baik.

2. Presisi

Keseksamaan (precision) adalah ukuran yang menunjukkan derajat kesesuaian hasil uji individual, diukur melalui penyebaran hasil individual dari rata-rata jika prosedur diterapkan secara berulang pada sampel-sampel yang diambil dari campuran yang homogen. Keseksamaan diukur sebagai 
simpangan baku atau simpangan baku relatif (koefisien variasi). Keseksamaan dapat dinyatakan sebagai keterulangan (repeatability) atau ketertiruan (reproducibility). Keterulangan adalah keseksamaan metode jika dilakukan berulang kali oleh analis yang sama pada kondisi sama dan dalam interval waktu yang pendek. Keterulangan dinilai melalui pelaksanaan penetapan terpisah lengkap terhadap sampel-sampel identik yang terpisah dari batch yang sama, jadi memberikan ukuran keseksamaan pada kondisi yang normal (Harmita, 2004). Nilai presisi dapat ditentukan dengan membandingkan Relative Standard Deviasion (RSD) atau Coeficient Variation (CV) dengan syarat keberterimaan. Kriteria seksama diberikan jika metode memberikan nilai \%RSD $\leq 2 \%$ (Harmita, 2004). Hasil nilai presisi dapat dilihat pada Tabel 1.

Tabel 1. Tabel hasil presisi

\begin{tabular}{cccccc}
\hline \multirow{2}{*}{ Replikasi } & \multicolumn{5}{c}{ Absorbansi } \\
\cline { 2 - 6 } & $\mathbf{4} \mathbf{~ p p m}$ & $\mathbf{6} \mathbf{~ p p m}$ & $\mathbf{8} \mathbf{~ p m ~}$ & $\mathbf{1 0} \mathbf{~ p m}$ & $\mathbf{1 2} \mathbf{~ p m}$ \\
\hline 1 & 0,275 & 0,400 & 0,552 & 0,671 & 0,801 \\
2 & 0,267 & 0,401 & 0,541 & 0,676 & 0,831 \\
3 & 0,271 & 0,399 & 0,539 & 0,680 & 0,818 \\
4 & 0,275 & 0,400 & 0,542 & 0,687 & 0,821 \\
5 & 0,273 & 0,398 & 0,547 & 0,688 & 0,831 \\
6 & 0,266 & 0,399 & 0,550 & 0,677 & 0,837 \\
\hline $\bar{x}$ & 0,271 & 0,400 & 0,545 & 0,680 & 0,823 \\
SD & 0,004 & 0.001 & 0,005 & 0,007 & 0,013 \\
RSD (\%) & 1,446 & 0,263 & 0,967 & 0,973 & 1,572 \\
\hline
\end{tabular}


Berdasarkan data pada Tabel 1 menunjukkan bahwa nilai standar deviasi yang diperoleh dari konsentrasi 4-12 ppm adalah kurang dari 0,02 dan diperoleh nilai \%RSD $\leq$ 2\%. Hasil yang diperoleh menunjukkan bahwa metode uji yang digunakan pada penentuan vitamin $\mathrm{C}$ menggunakan spektrofotometri UVvisibel telah memenuhi syarat nilai \%RSD yang diterima.

3. Akurasi

Kecermatan dapat ditentukan dengan dua cara yaitu metode simulasi (spiked-placebo recovery) dan metode penambahan baku (standard addition method). Pada penelitian ini menggunakan metode adisi yaitu metode penambahan baku. Sampel dianalisis lalu sejumlah tertentu analit yang diperiksa ditambahkan ke dalam sampel, dicampur, dan dianalisis lagi (Harmita, 2004). Pemilihan metode ini dimaksudkan karena senyawa yang diuji merupakan metabolit sekunder.

$$
\text { Akurasi dimaksudkan untuk }
$$
mengetahui seberapa dekat antara hasil yang diukur dengan menggunakan suatu metode analisis dengan hasil yang sebenarnya. Akurasi dinyatakan dalam \% perolehan kembali (recovery), semakin sedikit selisih antar keduanya maka akurasi metode analisis semakin baik. Hasil akurasi dapat dilihat pada Tabel 2.

Uji akurasi yang dilakukan pada penelitian ini dinyatakan dengan persen perolehan kembali (recovery) menggunakan sampel ekstrak jeruk keprok yang sudah diketahui kadar vitamin C dalam ekstrak tersebut, sehingga dapat dilihat selisih penyimpangannya.

Tabel 2 menunjukkan bahwa \% recovery yang diperoleh yaitu $97,91-$ 104,16\%. Mulja dan Hanwar (2003) menyatakan bahwa range nilai \% recovery analit yang dapat diterima untuk sampel dengan kadar kecil adalah 90-110\%. Maka nilai \% recovery yang diperoleh dalam penelitian ini masuk dalam range yang dapat diterima sehingga dapat dikatakan metode ini memiliki akurasi yang baik.

4. Batas deteksi dan batas kuantifikasi

Batas deteksi adalah konsentrasi analit terendah dalam sampel yang masih dapat dideteksi, sedangkan batas kuantifikasi adalah konsentrasi analit terendah dalam sampel yang dapat ditentukan secara kuantitatif dengan presisi dan akurasi yang diterima (Gandjar dan Rohman, 2007). 
Penentuan batas deteksi dan deteksi 0,239 ppm. Nilai ini kuantifikasi untuk metode menunjukkan jumlah analit terkecil spektrofotometri UV-Vis berdasarkan yang masih dapat dideteksi dengan simpangan respon dan kemiringan metode spektrofotometri UV-Vis. (slope) kurva baku.

Hasil dari penentuan batas deteksi dan batas kuantifikasi dapat dilihat pada Tabel 3. Dari hasil perhitungan diperoleh nilai batas Batas deteksi yang dihasilkan adalah sebesar 0,724 ppm yang artinya pada konsentrasi tersebut bila dilakukan pengukuran masih dapat memberikan kecermatan.

Tabel 2. Tabel penentuan akurasi

\begin{tabular}{llrrrcc}
\hline Akurasi & Replikasi & Absorbansi & Ca & Ca* & Cf & Perolehan Kembali (\%) \\
\hline \multirow{2}{*}{$80 \%$} & 1 & 0,319 & 3,36 & 1,44 & 4,77 & 97,91 \\
& 2 & 0,319 & 3,36 & 1,44 & 4,77 & 97,91 \\
& 3 & 0,323 & 3,36 & 1,44 & 4,82 & 101,81 \\
& & $\bar{x}$ & & & & 99,13 \\
$100 \%$ & 2 & 0,408 & 4,2 & 1,8 & 6,05 & 103,22 \\
& 3 & 0,402 & 4,2 & 1,8 & 5,97 & 98,22 \\
& 1 & 0,405 & 4,2 & 1,8 & 6,01 & 100.81 \\
$120 \%$ & 2 & 0,493 & 5,04 & 2,16 & 7,29 & 104,16 \\
& 3 & 0,487 & 5,04 & 2,16 & 7,20 & 100,13 \\
& & 0,492 & 5,04 & 2,16 & 7,27 & 103,43
\end{tabular}

Keterangan: $\mathrm{Ca}=$ konsentrasi sampel sebenarnya, $\mathrm{Ca}^{*}=$ konsentrasi analit yang ditambahkan, $\mathrm{Cf}=$ konsentrasi total sampel hasil pengukuran.

Tabel 3. Nilai batas deteksi dan batas kuantifikasi vitamin C

\begin{tabular}{lc}
\hline Parameter & Nilai \\
\hline Batas Deteksi & $0,239 \mathrm{ppm}$ \\
Batas Kuantifikasi & $0,724 \mathrm{ppm}$ \\
\hline
\end{tabular}

Penentuan nilai batas deteksi dan batas kuantifikasi dalam suatu penelitian diperlukan untuk menentukan nilai yang akan dideteksi. Pentingnya dilakukan parameter tersebut agar dapat mengetahui batas nilai terkecil dari sampel yang masih dapat dideteksi 
pada spektrofotometri UV-Vis dan nilai kuantitas terkecil dari sampel yang masih dapat memenuhi kriteria kecermataan dan keseksamaan. Beberapa penelitian menyebutkan bahwa penentuan nilai batas deteksi tidak harus dilakukan karena nilai terkecil tersebut tidak selalu memberikan nilai kecermataan dan keseksamaan dalam penelitian.

Berdasarkan hasil penelitian yang telah dilakukan, mulai dari penentuan nilai linieritas, presisi, akurasi, batas deteksi, dan batas kuantifikasi, maka metode penetapan kadar vitamin C kulit jeruk keprok dengan menggunakan spektrofotometri UV-Vis memiliki nilai yang baik. Sehingga validasi metode penetapan kadar vitamin C dalam ekstrak kulit Jeruk Keprok dengan spetrofotometri UV-Vis sudah memenuhi parameter validasi.

Penetapan Kadar Vitamin C dalam Ekstrak Kulit Jeruk

Penetapan kadar dilakukan dengan membuat konsentrasi ekstrak kulit jeruk keprok 100 ppm yang dilakukan 3 kali replikasi dan diukur absorbansinya pada panjang gelombang $274,2 \mathrm{~nm}$. Kadar vitamin C dihitung dengan persamaan $y=0,069 x-0,01$ sehingga diperoleh kadar vitamin $C$ total adalah 51,88 mg/g atau 5,188\% (Tabel 4). Penelitian tentang kulit jeruk keprok telah dilakukan oleh Yunita dan Hasanudin (2018) dengan menjadikan sebuah sediaan krim berbasis cera alba. Namun penelitian tentang kadar kulit jeruk belum pernah dilakukan sebelumnya. Penelitian lain tentang vitamin C pada jeruk dilakukan oleh Helmiyesi dan Prihastanti (2008) menyatakan bahwa kadar vitamin $\mathrm{C}$ buah jeruk adalah 18,90 mg/100 gram atau $18,90 \%$ dari daging buah. Alfi (2017) menyatakan bahwa kadar vitamin C jeruk mandarin diperoleh sebesar 23,57\%. Penetapan kadar vitamin C pada jeruk juga dilakukan oleh Haitami dan Muntaha (2017) yang menghasilkan 38,42\% vitamin C dalam jeruk sunkist. Terlihat perbedaan yang sangat jauh pada beberapa hasil penelitian lain dengan kadar yang dihasilkan pada kulit jeruk keprok. Hal itu karena perbedaan bagian buah yang diteliti dan juga spesies jeruk yang digunakan. 
Vol.16 No. 01 Juli 2019

Tabel 4. Penetapan kadar ekstrak kulit jeruk keprok

\begin{tabular}{ccc}
\hline Replikasi & Absorbansi & Kadar Vitamin C (ppm) \\
\hline 1 & 0,346 & 5,159 \\
2 & 0,348 & 5,188 \\
3 & 0,350 & 5,217 \\
& $\bar{X}$ & 5,188 \\
& SD & 0,029 \\
\hline
\end{tabular}

\section{Simpulan}

Berdasarkan hasil penelitian
dapat disimpulkan bahwa metode penetapan kadar Vitamin C pada ekstrak kulit jeruk keprok telah memenuhi paramater validasi. Persamaan regresi yang diperoleh yaitu $y=0,069 x-0,01$ dengan nilai $r=0,999$, presisi dengan nilai $\mathrm{RSD}<2 \%$, perolehan kembali pada rentang 97,91-104,16\%, batas deteksi $0,239 \mathrm{ppm}$, dan batas kuantifikasi 0,724 ppm. Kadar vitamin C pada ekstrak kulit jeruk keprok adalah 51,88 mg/g.

\section{Daftar Pustaka}

Alfi, F. 2017. Uji aktivitas antioksidan dan kadar vitamin C jeruk mandarin (Citrus reticulata) segar dan kemasan. Skripsi. Jurusan Analis Kesehatan, Politeknik Kesehatan Kemenkes Surabaya.

Ball, J.S. 1997. Fruit Growing. New Delhi: Kalyani Publishers.

Gandjar, I.G. dan Rohman, A. 2007. Kimia Farmasi Analisis. Yogyakarta: Pustaka Pelajar.
Haitami, A.U. dan Muntaha, A. 2017. Kadar vitamin $C$ jeruk sunkist peras dan infused water. Jurnal Medical Laboratory Technology Journal, 3(1):98-102.

Harmita. 2004. Petunjuk pelaksanaan validasi metode dan cara perhitungannya. Majalah IImu Kefarmasian, I(3):117-135.

Helmiyesi, R.B. dan Prihastanti, E. 2008. Pengaruh lama penyimpanan terhadap kadar gula dan vitamin C pada buah jeruk siam (Citrus nobilis var, microcarpa). Jurnal Buletin Anatomi dan Fisiologi, 16(2):33-37.

Karsinah, S., Purnomo, Sudjidjo, dan Sukarmin. 2002. Perbaikan Tekstur Buah Jeruk Siam melalui Hibridasi. Seminar hasil penelitian tahun 2002. Solok: Balai Penelitian Tanaman Buah.

Kealey, D. dan Haines, P.J. 2002. Instant Notes Analytical Chemistry. New York: BIOS Scientific Publishers Limited.

Mulja, M. dan Hanwar, D. 2003. Prinsipprinsip cara berlaboratorium yang baik (good laboratory practice). Majalah Farmasi Indonesia Airlangga, III(2):71-76. 
Putri, M.P. dan Herwidiani, Y. 2015. Analisis kadar vitamin $C$ pada buah nanas segar (Ananas comosus (L.) Merr) dan buah nanas kaleng dengan metode spektrofotometri UV-Vis. Jurnal Wiyata, 2(1):34-38.

Riyanto. 2014. Validasi \& Verifikasi Metode Uji. Yogyakarta: Deepublish.

Tranggono, R.I. dan Latifah, F. 2007. Buku Pegangan IImu Pengetahuan Kosmetik. Jakarta: PT. Gramedia Pustaka Utama.
Wirakusumah, S.E. 2002. Buah dan Sayur untuk Terapi. Yogyakarta: Swadaya.

Yunita, E. dan Hasanudin, M. 2018. Formulasi dan uji sifat fisik sediaan krim ekstrak kulit jeruk keprok (Citrus reticulata) menggunakan basis cera alba. Jurnal Penelitian Farmasi Indonesia, 7(1):29-33.

Zahara, F. 2002. Pengaruh zat pengatur tumbuh terhadap pembentukan dan pengukuran tunas mikro pada Citrus nobilis secara in vitro. Jurnal Kultura, 37(2):22-25. 